\title{
Pathogen Reduction Technologies: The Best Solution for Safer Blood?
}

\section{Susanne Maria Picker*}

University Hospital of Cologne, 65 Lippstadt, Germany

\begin{abstract}
Although it is generally accepted that blood has never been safer than today, transfusion-associated side effects, particularly infective, still occur. Unlike screening strategies, pathogen reduction technologies offer a new approach to increase blood safety by actively/directly targeting possible, also emerging pathogens or donor leukocytes. Advanced technologies for cellular blood products like the psoralen-based INTERCEPT BLOOD SYSTEM or the riboflavin-based Mirasol pathogen reduction technology system have extensively been examined and are on the way to enter the blood bank routine. However, as with any medical treatment, the transfusion of pathogen reduced blood products is not completely risk-free. Due to possible impairment of the treated blood cells the transfusion success is significantly lower as compared to untreated blood products. Long-term side effects concerning the photosensitizers and their photoproducts still remain a matter of debate. This paper outlines current pathogen reduction technologies but also focuses on ethical concerns associated with the employment of these techniques.
\end{abstract}

Keywords: Pathogen reduction technology; Blood safety; Intercepts blood system; Mirasol PRT system; S-303 PRT system; UVC irradiation; THERAFLEX UV platelets system; THERAFLEX MB plasma system

\section{Current Safety of Blood Products}

Current strategies to reduce the risk of transmissible, transfusionassociated infections rely on donor deferral and testing procedures, filtration or gamma irradiation of blood products to reduce the number of leukotropic viruses and viable donor leukocytes promoting adverse transfusion reactions in the recipient $[1,2]$. The risk-benefit ratio of standard blood products is mainly represented by the infection incidence in the respective donor population. In the E.U., risk estimates for traditional transfusion-associated viruses (or parasites) are exceedingly rare and vary between 1 and $>10$ millions $[3,4]$. In Germany, the estimated risk for transfusion-associated infections with respect to hepatitis B virus (HBV) is $1: 360,000$, to hepatitis C virus (HCV) 1:10.9 millions, and to human immunodeficiency virus (HIV) 1: 4.3 millions [5]. Thus, the problem concerning these viruses seems to be managed. However, a residual risk still remains concerning pathogens for which actually no detection system exists (i.e. emerging viruses like the arbovirus, the agent for chikungunya) or the "window period", when blood levels of specific disease markers are too low for detection (i.e. shortly after infection). Nucleic acid testing has markedly reduced but not completely eliminated this period.

\section{The Rationale for Pathogen Reduction Technologies}

Meanwhile, bacterial contamination, especially of platelet (PLT) concentrates (PCs) due to their storage at ambient temperature allowing for bacterial proliferation, is recognized as the most common cause of transfusion-transmitted infections. Up to $0.6 \%$ of PCs from routine production might be bacterially contaminated [6], and the estimated mortality risk of severe post-transfusion sepsis ranges from 1:230,000 to $1: 625,000$ donor exposures [7-9]. Thus, bacterial (not viral) contamination might become the driving force leading to broad implementation of pathogen reduction technologies (PRTs) that are able to inactivate small numbers of bacteria (even when anaerobic) below the detection limit of screening methods. The latter require time for the organisms to proliferate prior to detection (generally $>36$ hours) $[10,11]$ and implicate the risk of false -positive or -negative results [12]. Of note, applied virus inactivation steps like solvent-detergent, $\beta$-propiolactone treatment or nanofiltration have markedly increased the safety of plasma (derivates), but are not suitable for cellular blood products, as they irreversibly damage cellular membranes and function.

\section{Pathogen Reduction Technologies for Cellular Blood Products}

Since the beginning of the 1990s, considerable progress has been made in the development of PRTs for cellular blood products, and some have already entered routine blood bank users, thus clinical practice. Such PRTs are based on photosensitizers, which are added during processing and, after being activated, generate active oxygen species or utilize electron transfer processes that are oxygen independent to predominantly damage nucleic acids (photodynamic reactions). Another class of agents irreversibly form covalent cross-links in nucleic acids (photochemical reactions) to prevent transcription, translation, and growing of the pathogen. The rationale for targeting nucleic acids is that pathogens and white blood cells require nucleic acid function not required for the therapeutic effects of PLTs, plasma, and red blood cells (RBCs). The reduction capacity should reach at least 4-6 $\log 10$ steps. Currently, the most intensive studied dyes with photodynamic properties are the essential vitamin B2 (riboflavin RB) and the phenothiazine derivative methylene blue (MB), while dyes with photochemical properties include psoralens (PS) like S-59 (amotosalen$\mathrm{HCl}$ ) and S-303 or the inactine PEN110. The latter compounds also interfere in nucleic acids by alkylation chemistry but become activated by other mechanisms than an external light source, i.e. upon $\mathrm{pH}$ shift, which is important for RBCs, whose hemoglobin strongly absorbs ultraviolet (UV) light.

Additionally, PRTs are considered to be as effective as gamma

*Corresponding author: Susanne Maria Picker, University Hospital of Cologne, 65 Lippstadt, Germany, Tel: +49-2941-62842; E-mail: Susanne.picker@uk-koeln.de

Received October 01, 2012; Accepted October 22, 2012; Published October 24 2012

Citation: Picker SM (2012) Pathogen Reduction Technologies: The Best Solution for Safer Blood? J Blood Disorders Transf 3:133. doi:10.4172/2155-9864.1000133

Copyright: @ 2012 Picker SM. This is an open-access article distributed under the terms of the Creative Commons Attribution License, which permits unrestricted use, distribution, and reproduction in any medium, provided the original author and source are credited. 
irradiation to prevent transfusion-associated graft versus host disease due to the capacity to inactivate donor leukocytes [13-15].

\section{Overview Over the Most Advanced Pathogen Reduction Technologies}

Long-term effects of photochemicals used in current PRT methods (Figure 1) followed by irradiation with visible or UV light cannot completely be excluded even when phase-III trials have been performed. Additionally, photosensitizers bear the potential to induce immune responses in the recipient, who can form antibodies that can bind to the altered blood cells and cause them to be cleared from the circulation. Until now, such an immune response has not been reported for PS-UVA, RB-UV, MB-light, nor UVC irradiation but has been seen for S-303 and PEN110 treated RBCs [16,17]. Studies on PRT treated plasma or PCs are more advanced than those with RBCs or even whole blood (WB). This may be because bacterial contamination is highest in PCs. Moreover, RBCs represent a more difficult environment due to the absorption spectrum of hemoglobin, the higher viscosity, and the prolonged storage time increasing e.g. hemolysis and potassium leakage.

The most highly investigated technology is based on photochemical treatment using amotosalen-HCl and UVA (INTERCEPT BLOOD SYSTEM, Cerus, Corp., Concord, USA) [18-26]. More recently, other systems using RB-UV (Mirasol PRT system, Terumo BCT Biotechnologies, Lakewood, USA), MB-light (THERAFLEX MB Plasma system, Blood Center of the German Red Cross NSTOB, institute Springe, in association with MacoPharma International GmbH, Tourcoing, France), or UVC alone (THERAFLEX UV-Platelets system, Forschungsgemeinschaft der DRK Blutspendedienste (German Red Cross) in association with MacoPharma) have been developed but are not yet routinely available.

\section{The mirasol PRT system for PCs, plasma and WB}

This RB-based system is currently investigated in ongoing clinical trials (IPTAS, PRESS, PREPARES) and available for routine use in several locations in Europe and the Middle East. The system has been shown to be effective against a variety of clinically relevant pathogens (reduction up to 4-6 $\log 10$ steps). It has demonstrated $98 \%$ efficacy against bacterial strains responsible for most of severe infections following transfusion [27]. To date, the Mirasol PRT system is the only PRT technology that has demonstrated inactivation of the nonenveloped viruses such as the hepatitis A virus (HAV) that is highly resistant to chemical and heat-mediated interventions [28]. The methodology is currently under development for the treatment of WB. Preliminary results suggest good retention of blood cell functionality so that PRT of all blood products using the same system may become achievable in the near future.
$35 \mathrm{ml}$ of RB (at a final concentration of $50 \mu \mathrm{M}$ ) is added to the respective blood product, which then is illuminated with UV light (265-370 nm, 4-6 min, dose 6.2 J/ml). Most of the applied energy is in the UVB range (280-315 $\mathrm{nm}$ ), a lesser amount in the UVA range $(315-400 \mathrm{~nm})$. The peak wavelength $(313 \mathrm{~nm})$ preferentially targets RBinduced damage to nucleic acids and does not emit energies, where cytochromes and other essential cofactors for mitochondrial function/ activity absorb. As an essential vitamin, RB and its photoproducts do not require subsequent removal from the treated blood component providing minimal blood cell loss.

\section{The INTERCEPT BLOOD SYSTEM for PCs and plasma}

The PS-based system is available and utilized in several European countries including Germany. A total of over 700,000 PS-UVA treated blood products have been transfused, and neither observational studies $[26,29]$ nor the hemovigilance program $[30,31]$ showed any unexpected safety concern. Like Mirasol PRT, the INTERCEPT BLOOD SYSTEM has proven sufficient reduction capacity against many pathogens (up to $4-7 \log 10$ steps) including bacteria. The efficiency, with which nonenveloped viruses can be inactivated, varies strongly. Of note, HAV is not susceptible to inactivation [32].

$17.5 \mathrm{ml}$ of amotosalen- $\mathrm{HCl}$ (at a final concentration of $150 \mu \mathrm{M}$ ) is added to plasma or PCs resuspended in InterSol (Fenwal, Deerfied, USA) or SSP+ (MacoPharma). Thereafter, the mixture is illuminated with UVA light (320-400 nm, 4-6 min, dose $3 \mathrm{~J} / \mathrm{cm} 2)$. Shorter wavelengths were shown to have detrimental effects on proteins through the generation of active oxygen species. After the photoreduction process, amotosalen and free photoproducts are adsorbed in a compound adsorptions device (CAD) for 10-20 min (plasma) or 4-16 hours (PCs). The treated blood component is then transferred into the final storage bag. Due to CAD treatment and several transfer steps, a volume and blood cell loss of about $12 \%$ may be observed [33]

\section{UVC irradiation of PCs and plasma}

The THERAFLEX UV-Platelets system is currently under evaluation for its efficacy and safety. The process is based on the application of UVC light (200-280 nm) combined with intensive agitation of the blood component. Since no photosensitizer needs to be added, toxicity-related adverse events associated with such agents can be excluded. The irradiation process results predominantly in the formation of cyclobutane pyrimidine and pyrimidine-pyrimidine dimers blocking the elongation of nucleic acid transcripts. Due to the different absorption characteristics of nucleic acids and proteins, the irradiation process mainly affects leukocytes and pathogens (by at least 4-6 $\log 10$ steps), while coagulation proteins and PLT function are largely preserved [34]. UVC irradiation failed to effectively inactivate spores (having a low impact in blood products), West Nile virus and especially HIV (for which screening is performed) [35,36]. Disruption
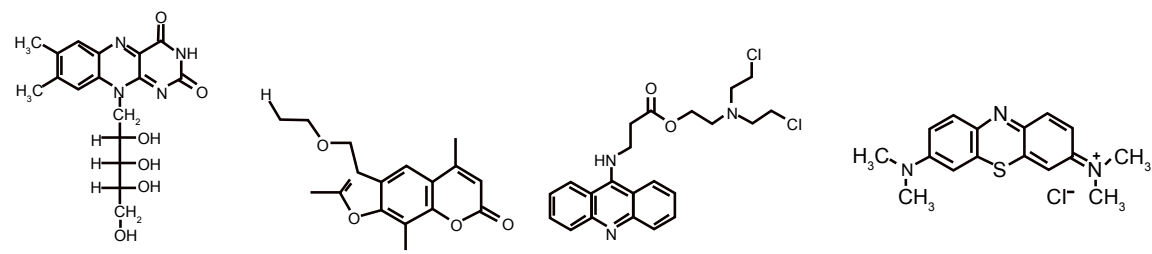

riboflavin (vitamin $\mathrm{B}_{2}$ )

amotosalen $\mathrm{HCl}$

S-303

methylene blue

Figure 1: Chemical structures of the most important photosensitizers. 
of disulfide bonds of the fibrinogen receptor (glycoprotein IIb-IIIa) described for UVC irradiation as "PLT sunburn" [37] appears to only be slightly increased using the THERAFLEX UV procedure as seen from the low increase of free thiol groups on the PLT surface [34].

Resuspended PLTs are transferred into a UVC permeable $19 \times 38$ $\mathrm{cm}$ illumination bag. Then UVC irradiation $(254 \mathrm{~nm}, 20-30 \mathrm{~s}$, dose $0.2 \mathrm{~J} / \mathrm{cm} 2(1 \mathrm{~J} / \mathrm{cm} 2$ for plasma)) is performed using a special UVC irradiation device (Mactronic, MacoPharma) where the bags are loosely placed on a quartz plate. Since the pathogen reduction capacity was shown to have its maximum at $\geq 100$ rotations per minute (rpm), the plate is agitating at $110 \mathrm{rpm}$. After illumination, the PLTs are transferred into the final storage container and ready for transfusion without further processing.

\section{The S-303 PRT system for RBCs}

The photochemical-based PRT system for erythrocytes has the capacity to effectively reduce pathogens by $4-6 \log 10$ steps but is currently not yet available in routine use [38]. S-303 is composed of an effector (an acridine moiety), a linker (alkyl chain) and an anchor (mustard hydrochloride moiety). It is designed to target nucleic acids, cross-link them via a bis-alkylating group and release a negatively charged nonreactive byproduct (S-300). S-300 is then captured by glutathione (GSH) also added to the blood component to minimize the non-specific reactions with proteins. A second generation system was developed after the observation of an unexpected immune response in 2 of 16 patients suffering from chronic anemia, who required more than a single transfusion of RBCs for therapeutic support [11]. The technology has also shown promise for application to WB [39].

$30 \mathrm{ml}$ of GSH and S-303 in saline are mixed with the blood product (to a final concentration $200 \mathrm{mM}$ GSH and $0.2 \mathrm{mM} \mathrm{S}-303$ ). The whole mixture is then transferred into a 2 nd container to allow both, the pathogen reduction process $(30 \mathrm{~min})$ and the decomposition of S-303 to S-300 (6-18 hours). After centrifugation, the supernatant is removed, and the treated RBCs are transferred into the final storage container containing additive solution for storage for up to 35 days at $4 \pm 2^{\circ} \mathrm{C}$.

\section{The THERAFLEX MB (TMB) Plasma system for plasma}

In contrast to PRT treated PCs and RBCs, PRT treated plasma has been in clinical use for several years and proven effective in a variety of therapeutic settings $[40,41]$. More than 4 million MB treated plasma units including about 2 million TMB treated plasma units have been generated to date [42]. For most enveloped viruses the pathogen kill power reaches at least $6 \log 10$ steps [43], but is considerably less for non-enveloped viruses. TMB treated plasma induces a reduction of clotting factor activities/life spans of 10-35\% including ADAMTS-13 [44]. Observational studies in Spain [45] and hemovigilance data from France [46], however, raise concern that MB treated plasma is probably less effective than quarantine plasma in the treatment of thrombotic thrombocytopenic purpura and may induce more severe, partly fatal allergic reactions.

At the start of the current TMB treated plasma system a $0.65 \mu \mathrm{m}$ membrane filter (Plasmaflex PLAS4, MacoPharma) removes residual leukocytes, RBCs, and PLTs as well as microvesicles and microparticles. Thereafter, the filtered plasma flows pass a dry "pill" containing 85 mg MB ensuring a final concentration of $1 \mu \mathrm{M}$ for a plasma volume ranging between 235 to $315 \mathrm{ml}$ The following illumination with visible light $\left(590 \mathrm{~nm}, 20 \mathrm{~min}\right.$, dose $\left.180 \mathrm{~J} / \mathrm{cm}^{2}\right)$ is achieved by sodium lowpressure lamps or light emitting diodes in a special device (Mactronic, MacoPharma). After treatment, residual MB and its photoproducts are removed by a special filter (Blueflex, MacoPharma) to an average level of $2 \mu \mathrm{g} / \mathrm{l}(0.5 \mu \mathrm{g} /$ plasma unit).

\section{Data from Preclinical Investigations}

PLTs treated with the INTERCEPT BLOOD SYSTEM or the Mirasol PRT system were associated with increased acidity and cell activation (increased p-selectin (CD62P) surface expression), enhanced metabolism (glucose consumption, lactate production), and reduced functional properties (aggregation, extent of shape change, hypotonic shock response HSR, etc.). Probably due to the fact that the applied wavelength energy differs from the absorbance energy of mitochondrial enzymes $(370-450 \mathrm{~nm})$, treatment with the Mirasol PRT system allowed the maintenance of the oxidative phosphorylation pathway, which was in contrast to amotosalen-UVA PRT treatment $[47,48]$. Mitochondrial respiration plays a critical role on PLT behavior during clot formation at sites of vascular injury [49]. In the absence of this functionality, reduced viability [50] and haemostatic effectiveness [51] may occur. After UVC irradiation of PCs HSR decreased by 20 $30 \%$ but recovered partly during storage [34]. All in all, in vitro quality of UVC irradiated PLTs was shown to be comparable to other PRTs [19,52-54].

\section{Data from Clinical Investigations}

Patients transfused with PRT treated PLTs demonstrated reduced post-transfusional corrected count increments (CCIs) leading to an average of $35 \%$ more transfusions [24,25,55]. This was mainly considered as the result of the lower PLT dose after PRT treatment due to multiple bag transfers and CAD treatment, but an intrinsic storage lesion development might also have contributed to this finding. From the frequency of bleeding events PRT treated PLTs were hemostatically as effective as their untreated counterparts reinforced by data of a hemovigilance program $[30,31]$ and similar values for invitro aggregability under flow conditions [56] relative to untreated PLTs. However, a recent clinical investigation on PS-UVA treated PCs was stopped prematurely due to significantly more hemorrhagic events [57]. Indeed, decreased shear induced adhesion properties of PS-UVA treated PLTs (although not significant) were observed in our investigation [51]. Hemovigilance programs arelikely too underpowered to really detect such discrepancies that might be overcome by increased transfusion doses. Due to equal frequencies of adverse events, PRT treated PLTs were considered as safe as conventional PCs. Although reduced, recovery and survival rates of radiolabeled, PRT treated PLTs were considered as being still acceptable for transfusion [58], even after UVC irradiation [59]. Nevertheless, study sizes appear far too small to draw any firm conclusion in this respect.

Nearly all phase-III studies on S-303 treated RBCs were suspended when 2 of 16 chronically transfused patients developed positive crossmatch reactions to S-303 treated RBCs. The underlying low-titer antibodies (that also could naturally occur [60]) were directed against the surface-bound acridine moiety of S-303 [61]. A $2^{\text {nd }}$ generation pathogen inactivation process was developed minimizing the amount of RBC-bound acridine. Preliminary results using this container $(n=27)$ [38] indicated that the treated RBCs maintained sufficient viability (24 hour recovery rates of about $88 \%$ ) and did not induce positive crossmatches [62].

\section{Conclusions}

Open questions of current PRTs still remain concerning the extent to which all (un)known pathogens including non-enveloped viruses 
or prions can be reduced. Before broad implementation, it has to be shown, that the photosensitizers and their photoproducts are extremely safe, robust in daily routine, cost-effective and controllable in their efficacy. Toxicological studies are difficult to perform and may not reveal rare events like carcinogenicity that only can be detected during long-term observation. Any benefit gained from the use of PRT treated blood products may be offset by any incidence of an unanticipated adverse event [63]. Finally, PRTs must preserve sufficient therapeutic effectiveness of the treated blood cells. Compared to untreated PLTs, however, PRT treated PLTs seem to be functionally inferior and led to increased transfusion requirements due to lower CCIs. Whether CCIs have sufficient clinical sensitivity and specificity is still a subject of debate [64]. Evaluation of PLT function before and after transfusion via new approaches (i.e. thromboelastography) or the careful evaluation of bleeding events appears more appropriate highlighting the role of further clinical trials.

\section{References}

1. Heddle NM, Klama L, Singer J, Richards C, Fedak P, et al. (1994) The role of the plasma from platelet concentrates in transfusion reactions. N Engl $\mathrm{J}$ Med 331: 625-628.

2. Klüter H, Bubel S, Kirchner H, Wilhelm D (1999) Febrile and allergic transfusion reactions after the transfusion of white cell-poor platelet preparations. Transfusion 39: 1179-1184.

3. Caspari G, Gerlich WH, Kiefel V, Gürtler L (2005) Pathogen inactivation of cellular blood products - still plenty of reason to be careful. Transfus Med Hemother 32: 258-260.

4. Seifried E, Findhammer S, Roth WK (2002) Status of NAT screening for HCV HIV and HBV--experiences of the German Red Cross Blood Donation Services. Dev Biol (Basel) 108: 23-27.

5. Hourfar MK, Jork C, Schottstedt V, Weber-Schehl M, Brixner V, et al. (2008) Experience of German Red Cross blood donor services with nucleic acid testing: results of screening more than 30 million blood donations for human immunodeficiency virus-1, hepatitis $C$ virus, and hepatitis B virus. Transfusion 48: 1558-1566

6. Walther-Wenke G, Doerner R, Montag T, Greiss O, Hornei B, et al. (2006) Bacterial contamination of platelet concentrates prepared by different methods: results of standardized sterility testing in Germany. Vox Sang 90: 177-182.

7. Blajchman MA (2002) Incidence and significance of the bacterial contamination of blood components. Dev Biol (Basel) 108: 59-67

8. Ness P, Braine H, King K, Barrasso C, Kickler T, et al. (2001) Single-donor platelets reduce the risk of septic platelet transfusion reactions. Transfusion 41: 857-861.

9. Perez P, Salmi LR, Folléa G, Schmit JL, de Barbeyrac B, et al. (2001) Determinants of transfusion-associated bacterial contamination: results of the French BACTHEM Case-Control Study. Transfusion 41: 862-872.

10. Brecher ME, Hay SN (2003) The role of bacterial testing of cellular blood products in light of new pathogen inactivation technologies. Blood Ther Med 3: 49-55.

11. Klüter $H$ (2002) The struggle for safer blood: pathogen inactivation of cellular blood preparations. Blood Ther Med 2: 42-47.

12. Schrezenmeier $H$, Walther-Wenke $G$, Müller TH, Weinauer $F$, Younis $A$, et al. (2007) Bacterial contamination of platelet concentrates: results of a prospective multicenter study comparing pooled whole blood-derived platelets and apheresis platelets. Transfusion 47: 644-652

13. Hei DJ, Grass J, Lin L, Corash L, Cimino G (1999) Elimination of cytokine production in stored platelet concentrate aliquots by photochemical treatment with psoralen plus ultraviolet A light. Transfusion 39: 239-248.

14. Corash L, Lin L (2004) Novel processes for inactivation of leukocytes to prevent transfusion-associated graft-versus-host disease. Bone Marrow Transplant 33: $1-7$.

15. Fast LD, DiLeone G, Marschner S (2011) Inactivation of human white blood cells in platelet products after pathogen reduction technology treatment in comparison to gamma irradiation. Transfusion 51: 1397-1404.
16. Benjamin RJ, McCullough J, Mintz PD, Snyder E, Spotnitz WD, et al. (2005) Therapeutic efficacy and safety of red blood cells treated with a chemical process (S-303) for pathogen inactivation: a Phase III clinical trial in cardiac surgery patients. Transfusion 45: 1739-1749.

17. Zavizion B, Purmal A, Chapman J, Alford B (2004) Inactivation of mycoplasma species in blood by INACTINE PEN110 process. Transfusion 44: 286-293.

18. Knutson F, Alfonso R, Dupuis K, Mayaudon V, Lin L, et al. (2000) Photochemica inactivation of bacteria and HIV in buffy-coat-derived platelet concentrates under conditions that preserve in vitro platelet function. Vox Sang 78: 209-216.

19. van Rhenen DJ, Vermeij J, Mayaudon V, Hind C, Lin L, et al. (2000) Functiona characteristics of S-59 photochemically treated platelet concentrates derived from buffy coats. Vox Sang 79: 206-214.

20. Picker SM, Speer R, Gathof BS (2004) Functional characteristics of buffy-coat $\mathrm{PLTs}$ photochemically treated with amotosalen- $\mathrm{HCl}$ for pathogen inactivation. Transfusion 44: 320-329

21. Janetzko K, Cazenave JP, Klüter H, Kientz D, Michel M, et al. (2005) Therapeutic efficacy and safety of photochemically treated apheresis platelets processed with an optimized integrated set. Transfusion 45: 1443-1452.

22. Klein HG, Anderson D, Bernardi MJ, Cable R, Carey W, et al. (2007) Pathogen inactivation: making decisions about new technologies. Report of a consensus conference. Transfusion 47: 2338-2347.

23. Mintz PD, Bass NM, Petz LD, Steadman R, Streiff $M$, et al. (2006) Photochemically treated fresh frozen plasma for transfusion of patients with acquired coagulopathy of liver disease. Blood 107: 3753-3760.

24. van Rhenen D, Gulliksson H, Cazenave JP, Pamphilon D, Ljungman $P$, et al (2003) Transfusion of pooled buffy coat platelet components prepared with photochemical pathogen inactivation treatment: the euroSPRITE trial. Blood 101: 2426-2433

25. McCullough J, Vesole DH, Benjamin RJ, Slichter SJ, Pineda A, et al. (2004) Therapeutic efficacy and safety of platelets treated with a photochemical process for pathogen inactivation: the SPRINT Trial. Blood 104: 1534-1541.

26. Cazenave JP, Isola H, Waller C, Mendel I, Kientz D, et al. (2011) Use of additive solutions and pathogen inactivation treatment of platelet components in a regional blood center: impact on patient outcomes and component utilization during a 3-year period. Transfusion 51: 622-629.

27. Goodrich RP, Gilmour D, Hovenga N, Keil SD (2009) A laboratory comparison of pathogen reduction technology treatment and culture of platelet products for addressing bacterial contamination concerns. Transfusion 49: 1205-1216.

28. Marschner S, Goodrich R (2011) Pathogen reduction technology treatment of platelets, plasma and whole blood using riboflavin and UV light. Transfus Med Hemother 38: 8-18.

29. Osselaer JC, Messe N, Hervig T, Bueno J, Castro E, et al. (2008) A prospective observational cohort safety study of 5106 platelet transfusions with components prepared with photochemical pathogen inactivation treatment. Transfusion 48 1061-1071.

30. Cazenave JP, Waller C, Kientz D, Mendel I, Lin L, et al. (2010) An active hemovigilance program characterizing the safety profile of 7483 transfusions with plasma components prepared with amotosalen and UVA photochemical treatment. Transfusion 50: 1210-1219.

31. Osselaer JC, Cazenave JP, Lambermont M, Garraud O, Hidajat M, et al. (2008) An active haemovigilance programme characterizing the safety profile of 7437 platelet transfusions prepared with amotosalen photochemical treatment. Vox Sang 94: 315-323.

32. Infanti L, Stebler C, Job S, Ruesch M, Gratwohl A, et al. (2011) Pathogeninactivation of platelet components with the INTERCEPT Blood System TM cohort study. Transfus Apher Sci 45: 175-181.

33. Picker SM, Speer R, Gathof BS (2004) Evaluation of processing characteristics of photochemically treated pooled platelets: target requirements for the INTERCEPT Blood System comply with routine use after process optimization Transfus Med 14: 217-223.

34. Seltsam A, Müller TH (2011) UVC Irradiation for Pathogen Reduction of Platele Concentrates and Plasma. Transfus Med Hemother 38: 43-54.

35. Mohr H, Bachmann B, Klein-Struckmeier A, Lambrecht B (1997) Virus inactivation of blood products by phenothiazine dyes and light. Photochem Photobiol 65: 441-445. 
36. Mohr H, Steil L, Gravemann U, Thiele T, Hammer E, et al. (2009) A novel approach to pathogen reduction in platelet concentrates using short-wave ultraviolet light. Transfusion 49: 2612-2624.

37. Verhaar R, Dekkers DW, De Cuyper IM, Ginsberg MH, de Korte D, et al. (2008) UV-C irradiation disrupts platelet surface disulfide bonds and activates the platelet integrin alphallbbeta3. Blood 112: 4935-4939.

38. Henschler R, Seifried E, Mufti N (2011) Development of the S-303 Pathogen Inactivation Technology for Red Blood Cell Concentrates. Transfus Med Hemother 38: 33-42.

39. Mufti NA, Erickson AC, North AK, Hanson D, Sawyer L, et al. (2010) Treatment of whole blood (WB) and red blood cells (RBC) with S-303 inactivates pathogens and retains in vitro quality of stored RBC. Biologicals 38: 14-19.

40. Prowse C (2009) Properties of pathogen-inactivated plasma components Transfus Med Rev 23: 124-133.

41. Rock G (2011) A comparison of methods of pathogen inactivation of FFP. Vox Sang 100: 169-178.

42. Sandler SG (2010) The status of pathogen-reduced plasma. Transfus Apher Sci 43: 393-399.

43. Seghatchian J, Struff WG, Reichenberg S (2011) Main Properties of the THERAFLEX MB-Plasma System for Pathogen Reduction. Transfus Med Hemother 38: 55-64.

44. del Río-Garma J, Pereira A, Arroyo JL, Mateo J, Alvarez-Larrán A, et al. (2008) ADAMTS-13 activity and von Willebrand factor levels in methylene-blue photoinactivated plasma processed by either the Springe method or an 'in house' system. Vox Sang 95: 101-105.

45. del Río-Garma J, Alvarez-Larrán A, Martínez C, Muncunill J, Castellà D, et al. (2008) Methylene blue-photoinactivated plasma versus quarantine fresh frozen plasma in thrombotic thrombocytopenic purpura: a multicentric, prospective cohort study. Br J Haematol 143: 39-45.

46. Carlier M, Vo Mai MP, Fauveau L, Ounnoughene N, Sandid I, et al. (2011) Seventeen years of haemovigilance in France: assessment and outlook. Transfus Clin Biol 18: 140-150.

47. Picker SM, Steisel A, Gathof BS (2009) Cell integrity and mitochondrial function after Mirasol-PRT treatment for pathogen reduction of apheresis-derived platelets: Results of a three-arm in vitro study. Transfus Apher Sci 40: 79-85.

48. Picker SM, Oustianskaia L, Schneider V, Gathof BS (2009) Functional characteristics of apheresis-derived platelets treated with ultraviolet light combined with either amotosalen-HCl (S-59) or riboflavin (vitamin B2) for pathogen-reduction. Vox Sang 97: 26-33.

49. Akkerman JW (1978) Regulation of carbohydrate metabolism in platelets. A review. Thromb Haemost 39: 712-724.

50. Picker SM, Schneider V, Oustianskaia L, Gathof BS (2009) Cell viability during platelet storage in correlation to cellular metabolism after different pathogen reduction technologies. Transfusion 49: 2311-2318.
51. Picker SM, Schneider V, Gathof BS (2009) Platelet function assessed by shearinduced deposition of split triple-dose apheresis concentrates treated with pathogen reduction technologies. Transfusion 49: 1224-1232.

52. Ruane PH, Edrich R, Gampp D, Keil SD, Leonard RL, et al. (2004)Photochemica inactivation of selected viruses and bacteria in platelet concentrates using riboflavin and light. Transfusion 44: 877-885.

53. AuBuchon JP, Herschel L, Roger J, Taylor H, Whitley P, et al. (2005) Efficacy of apheresis platelets treated with riboflavin and ultraviolet light for pathogen reduction. Transfusion 45: 1335-1341.

54. Reikvam H, Marschner S, Apelseth TO, Goodrich R, Hervig T (2010) The Mirasol Pathogen Reduction Technology system and quality of platelets stored in platelet additive solution. Blood Transfus 8: 186-192.

55. Mirasol Clinical Evaluation Study Group (2010)A randomized controlled clinica trial evaluating the performance and safety of platelets treated with MIRASOL pathogen reduction technology. Transfusion 50: 2362-2375

56. Lozano M, Galan A, Mazzara R, Corash L, Escolar G (2007) Leukoreduced buffy coat-derived platelet concentrates photochemically treated with amotosalen $\mathrm{HCl}$ and ultraviolet $\mathrm{A}$ light stored up to 7 days: assessment of hemostatic function under flow conditions. Transfusion 47: 666-671.

57. Kerkhoffs JL, van Putten WL, Novotny VM, Te Boekhorst PA, Schipperus MR et al. (2010) Clinical effectiveness of leucoreduced, pooled donor platele concentrates, stored in plasma or additive solution with and without pathogen reduction. Br J Haematol 150: 209-217.

58. Goodrich RP, Woolum A, Hansen E (2001) Recovery and survival of radiolabelled platelets following treatment with a riboflavin based pathogen inactivation procedure. Blood 98:541a.

59. Bashir S, Cookson P, Wiltshire M, Hawkins L, Sonoda L, et al. (2012) Pathogen inactivation of platelets using ultraviolet $\mathrm{C}$ light: effect on in vitro function and recovery and survival of platelets. Transfusion

60. North A, Propst M, Henschler R, Geisen C, Garratty G, et al. (2010) Evolution of naturally occurring antibodies to pathogen inactivated red blood cells. Transfusion 50: 38A.

61. North AK, Castro G, Erickson A, Cook D, Corash L (2007) Characterization of antibodies to red cells prepared with $\mathrm{S}-303$ pathogen inactivation treatment Vox Sang 93: 167-168.

62. Cancelas JA, Dumont LJ, Rugg N, Szczepiorkowski ZM, Herschel L, et al. (2011) Stored red blood cell viability is maintained after treatment with a secondgeneration S-303 pathogen inactivation process. Transfusion 51: 2367-2376

63. Bell CE, Botteman MF, Gao X, Weissfeld JL, Postma MJ, et al. (2003) Costeffectiveness of transfusion of platelet components prepared with pathogen inactivation treatment in the United States. Clin Ther 25: 2464-2486.

64. Slichter SJ, Kaufman RM, Assmann SF, McCullough J, Triulzi DJ, et al. (2010) Dose of prophylactic platelet transfusions and prevention of hemorrhage. $\mathrm{N}$ Engl J Med 362: 600-613. 